\title{
Politeness in Using Banjarese and American English Personal Subject Pronouns by English Department Students of Lambung Mangkurat University
}

\author{
Elvina Arapah \\ English Department, Lambung Mangkurat University, Banjarmasin, Indonesia \\ Fatchul Mu'in \\ English Department, Lambung Mangkurat University, Banjarmasin, Indonesia
}

\begin{abstract}
This research is aimed at describing the use of personal pronouns of Banjarese and American English.The research uses the Convergent Parallel Design. Data are collected by using two kinds of questionnaires. The first is for 37 students belonging to Banjar Kuala Dialect (BKD), and the second is for 24 students belonging to Banjar Hulu Dialect (BHD). Research result shows that Banjarese and American English' pronouns are based on singular and plural distinction although Banjarese does not have a gender distinction as in the American English. The personal pronouns are the first, second and third persons. English personal pronouns depend mostly on the grammatical role while Banjarese personal pronouns can indicate the social status or the relation of the speaker and other persons in the discourse. Personal pronouns can reveal the social status, and they can the politeness or impoliteness of the speakers.
\end{abstract}

Index Terms - politeness, personal subject pronoun, Banjarese, and American English

\section{INTRODUCTION}

Banjarese-speaking people can be identified from their geographical dialects. There are two dialects of Banjarese. The first one is Banjar Kuala Dialect (BKD) spoken by people who live in areas of Banjarmasin, Banjarbaru, Marabahan, Pelaihari until Kotabaru. The other dialect is Banjar Hulu Dialect (BHD) used by people from Martapura, Tapin, Hulu Sungai Selatan, Hulu Sungai Tengah, Hulu Sungai Utara, Balangan and Tabalong.

Similarly, as one of the languages in the world, English also has variations known as American, British, Australian, Indian, and the others. American English is particularly not spoken in its continent of the fifty states only, but also is generally adapted and studied by people around the world. English Department students of Lambung Mangkurat University also learn and acquire American English.

Most of the students come from different background of Banjarese both dialects and they try to master English with their own 'unique' mother tongue, in which in the process of learning it might have influence on the acquisition of the English. The difficulties or the advantages that might occur are because Banjarese (Banjar Language) and American English have distinguished system of language. English does not have level of pronoun politeness like Banjarese unda, $a k u$, and ulun (I) to express the first singular pronoun. However, this might hamper or benefit the students when they are learning English as a foreign language.

This research tries to reveal the use of personal subject pronoun in Banjarese and English among students of English Department Lambung Mangkurat University Batch 2012. The research questions of the study are limited to these areas: (1) How do students of English Department, Lambung Mangkurat University Batch 2012 use the Banjarese personal subject pronouns?, Does the geographical place of origin influence their uses in terms of official and unofficial situations, degree of intimacy, social status, age, sex distinction, and marital status?, (2) How is the use of American English personal pronouns by the students of English Department, Lambung Mangkurat University Batch 2012?, and (3) How is the use of Banjarese and American English personal pronoun compared?

\section{LITERATURE REVIEW}

This part reviews some theoretical backgrounds related to the personal subject pronoun in Banjarese and American English. Furthermore, the politeness of the pronouns are also presented briefly.

\section{A. Politeness}

According to Richards and Schmidt (2002), politeness has two definitions: (a) how languages express the social distance between speakers and their different role relationships; (b) how facework that is the attempt to establish, 
maintain, and save face during conversation, is carried out in a speech community (p.405). Referring to the work of Brown and Levinson, Wardhaugh (2006) wrote that:

Positive politeness leads to moves to achieve solidarity through offers of friendship, the use of compliments, and informal language use: we treat others as friends and allies, do not impose on them, and never threaten their face. On the other hand, negative politeness leads to deference, apologizing, indirectness, and formality in language use: we adopt a variety of strategies so as to avoid any threats to the face others are presenting to us.

Based on the definitions and the classifications, it can be defined that politeness is the way a particular expression used between speakers, it marks the relationship of the first person and the interlocutors in which the connection might bring positive or negative politeness.

\section{B. Personal Subject Pronouns}

The geographical distribution of politeness distinctions in personal pronouns all over the world is different as it is found in dialect atlas. Indonesia belongs to the category of avoiding direct pronoun for the second person as in anda or you (Wales, 2004). Also, he stated that in addressing another, the choice of name which you use for the other depend both on your knowledge of exactly who that other is (e.g. his or her age and lineage) and on the circumstances of the meeting. Moreover, he mentioned that a variety of social factor usually governs the choice or terms: the particular occasion; the social status or rank of the other; sex; age; family relationship, occupational hierarchy; transactional status; race; or degree of intimacy. The choice is sometimes quite clear; when racial or caste origin is important in society that is likely to take preference; and so on.

According to Kartomiharjo (1979, p.186), in Indonesia the choice of personal pronoun (PP) reflect the identity and the relationship of the interlocutors Further, in his study (1979, p.128-171) about communicative codes in East Java, he listed that that choice of Personal Pronoun (PP) might be used in official and unofficial situation, depends on the degrees of intimacy, social status, age, sex distinction and marital status.

\section{The Banjarese Personal Subject Pronouns}

Banjarese has the politeness distinction like Javanese' unggah-ungguh, but it is specifically a matter of distinction in personal pronoun politeness. As a matter of fact, the Banjarese level of politeness is specifically seen on the use of personal pronouns - first, second and third.There are different variants of the politeness level for first and second pronouns as it is shown in Table 1 below.

TABLE 1

The LeVel of Politeness of B ANJARESE $1^{\mathrm{ST}}, 2^{\mathrm{ND}}$, AND $3^{\mathrm{RD}}$ PERSONAL SuBJECT PRONOUNS

\begin{tabular}{|c|c|c|c|c|c|c|}
\hline \multirow[t]{2}{*}{ Level of Politeness } & \multicolumn{2}{|c|}{ 1st Person Pronoun } & \multicolumn{2}{|c|}{ 2nd Person Pronoun } & \multicolumn{2}{|c|}{ 3rd Person Pronoun } \\
\hline & Singular (I) & $\begin{array}{l}\text { Plural } \\
\text { (we) }\end{array}$ & Singular (you) & Plural (you) & Singular (he, she, it) & Plural (they) \\
\hline \multirow[t]{2}{*}{ I (polite) } & ulun & kami & pian & buhan pian & sidin & buhan sidin \\
\hline & & & & & nang ini / nang itu & nang ini / nang itu. \\
\hline \multirow[t]{2}{*}{ II (neutral) } & aku & kami & ikam / sampiyan & $\begin{array}{l}\text { buhan ikam / } \\
\text { buhan sampiyan }\end{array}$ & inya & buhan inya \\
\hline & & & & & nang ini / nang itu & nang ini / nang itu. \\
\hline \multirow[t]{2}{*}{ III (considered rude } & unda & kami & nyawa & buhan nyawa & inya & buhan inya \\
\hline & & & & & nang ini / nang itu & nang ini / nang itu. \\
\hline
\end{tabular}

From the table, it can be seen that singular first and second person pronouns have three variants -ulun, aku, unda (I) and $a k u$, ikam, nyawa (you). In terms of singular third person pronoun, only two alternates exist. Those are sidin and inya. There is quite more or less the same terms used for the plural ones. The pronoun used shows the level of closeness of the speakers.

Beside those variants of personal subject pronoun, there also other pronouns which might be still in use. Saurang ini and Kita ini are used by speakers who does not have a long-standing relationship with one another or on the contrary. For example between two people who meet at the airport waiting room or two close friends who are involved in a conversation as in the sample sentence:

Mun saurang ni asa kada yakin nang itu jukungnya.

(I don't think that it is the boat)

Kita ini sudah rancak banar tarabang bapasawat ka mana-mana.

(I have often flied anywhere)

Yayang ini / $\mathrm{ni}$ is also possibly used when someone refer to himself or herself talking to an intimate person. for example:

Maksud yayang ni biar kita gawi haja dulu.

(What I mean is let us just do it, first)

Beliau is used to refer to someone in intention to give honor or respect the person

Beliau tu sudah cangkal haja bausaha, tapi pina kada kalihatan hasilnya. 
(He has tried enough; however, it doesn't seem to be successful)

Using name is in replacing the personal peronoun. It is especially to show closeness or just being spoiled, for examples:

Ari dimana sekarang?

(Where are you now, Ari?)

Dita kada bermaksud kaitu pang, Bu.

(Dita doesn't' mean it, Ma'am)

Terms of address kaka and ading can also be pronouns when the speakers and the interlocutors have a very strong relationship. The lexical meanings of kaka and ading are 'brother' and 'sister' in a family terms. In this relation, both are used as the polite terms in a male-female love relatioship, as in: Kaka ini sudah lawas handak wan ading (I have been in love with you for quite some time). The speaker addresses himself as kaka, and the second person (listener) as ading, indicating the subject and the object of sentence respectively.

\section{The American English Personal Subject Pronouns}

Richards and Schmidt (2002) in Longman Dictionary of Language Teaching and Applied Linguistics defined that personal pronouns is the set of pronouns which represent the grammatical category of PERSON, and which in English is made up of I, you, he, she, it, we, they, and their derived forms (e.g. me, mine, yours, him, his, hers, etc.).

English does not have politeness distinction in Personal Pronoun. Whatever the situation or context and whoever the interlocutor is, the pronouns used are the same. There is no change in terms of distinguishing the speakers. It is surely poles apart with the Banjarese personal subject pronouns which are categorized into three levels of politeness.

\section{METHOD}

\section{A. Research Design}

This research combines the quantitative and qualitative design in order to come into a conclusion. Both types of data are meant to support each other. This plan of mixed method is so-called Convergent Parallel Design. The quantitative data collection and the qualitative one are simultaneously collected, merged and used to make a conclusion of a research problem. The interpretation of the findings brings the conclusion of a comparison study strengthening the quantitative and qualitative result.

\section{B. Sources of Data and Sampling Technique}

The subjects of the research are English Department students of Lambung Mangkurat University Banjarmasin. The random sampling technique is applied by asking 100 respondents to fill out the questionnaire A and B. The respondents are taken randomly due to their willingness to participate and limited to the English Department students of Lambung Mangkurat University Batch 2012. From 100 pieces of questionnaire distributed, the respondents are categorized into to those students who use Banjar Kuala Dialect and Banjar Hulua Dialect in their formal or informal conversation. The categorization is based on the students' origin and place of birth.

To support the decision whether one is a dominant Banjar Kuala Dialect or Banjar Hulu Dialect speaker, some words in both dialects are asked to him / her to choose. Knowing or ever using certain word(s) might show that he or she is influenced or a speaker of a particular dialect. As a result, it is found out that 37 samples of respondent are Banjar Kuala Dialect and 24 samples are Banjar Hulu Dialect. It means that, out of 100 questionnaires, the rest 29 respondents do not qualify as a dominant native speaker of particular dialect.

For questionnaire C, only 40 students from Batch 2012, taken randomly, are asked to fill it out. They know how to speak English even though they have different levels of ability. In addition, their length of time in learning English is more or less the same, around $7-9$ years since elementary school or junior high school to university. In terms of gender, the respondents are male and females. All in all, those samples are analyzed differently between the speakers of Banjar Kuala Dialect or Banjar Hulu Dialect and the English as a Foreign Language (EFL) speakers.

\section{Data Collection}

The technique of data collection is questionnaire and the instrument used is questionnaire as well. There are three questionnaires used and the content validity is investigated by the researchers by extracting the ideas into indicators as it can be seen in the Table 3.1. The first two questionnaires are used to gather data about the use of Banjarese personal subject pronoun and the last questionnaire is to investigate the American English one. 
TABLE 3.1

THE TABLE OF SPECIFICATION OF THE QUESTIONNAIRES USED IN THE RESEARCH

\begin{tabular}{|c|c|c|c|}
\hline INSTRUMENT & 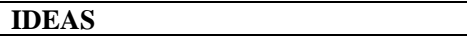 & SUB-IDEAS & QUESTION NUMBER \\
\hline \multirow[t]{28}{*}{ Questionnaire A } & sex & male, female & 1 \\
\hline & origin & South Borneo \& others & 2 \\
\hline & place of birth & South Borneo \& others & 3 \\
\hline & Banjarese dominantly used & BKD \& BHD & 4 \\
\hline & \multirow[t]{3}{*}{ official situation } & pronoun used in a forum & 5 \\
\hline & & inside the classroom & 6 \\
\hline & & respected person & 7 \\
\hline & unofficial situation & outside the classroom & 8 \\
\hline & \multirow[t]{4}{*}{ degree of intimacy } & boyfriend (girlfriend) / spouses & 9,13 \\
\hline & & close friend & 10,14 \\
\hline & & parents & 11,15 \\
\hline & & siblings & 12,16 \\
\hline & \multirow[t]{4}{*}{ social status } & unknown marital status & 17,21 \\
\hline & & known marital status & 18 \\
\hline & & unknown job & 19,22 \\
\hline & & known job & 20 \\
\hline & \multirow[t]{10}{*}{ age } & friend with similar age & 23 \\
\hline & & friend who is older & 24 \\
\hline & & friend who is younger & 25 \\
\hline & & sibling with similar age & 26 \\
\hline & & sibling who is older & 27 \\
\hline & & sibling who is younger & 28 \\
\hline & & new acquaintance who is older & 29 \\
\hline & & new acquaintance is younger & 30 \\
\hline & & someone older & 31 \\
\hline & & someone younger & 32 \\
\hline & \multirow{2}{*}{ sex distinction } & male & 33 \\
\hline & & female & 34 \\
\hline \multirow[t]{7}{*}{ Questionnaire B } & official \& unofficial situation & - & 1 \\
\hline & degree of intimacy & - & 2 \\
\hline & marital status & - & 3 \\
\hline & age & - & 4 \\
\hline & sex & - & 5 \\
\hline & other possible situations & - & 6 \\
\hline & other possible pronouns used & - & 7 \\
\hline \multirow[t]{10}{*}{ Questionnaire C } & the English $1^{\text {st }}$ personal subject pronoun & - & 1 \\
\hline & the English $2^{\text {nd }}$ personal subject pronoun & - & 2 \\
\hline & the English $3^{\text {rd }}$ personal subject pronoun & - & 3 \\
\hline & $\begin{array}{l}\text { the English singular personal subject } \\
\text { pronoun }\end{array}$ & - & 4 \\
\hline & $\begin{array}{l}\text { the English plural personal subject } \\
\text { pronoun }\end{array}$ & - & 5 \\
\hline & official \& unofficial situation & - & 6 \\
\hline & degree of intimacy & - & 7 \\
\hline & social status & - & 8 \\
\hline & age & - & 9 \\
\hline & sex & - & 10 \\
\hline
\end{tabular}

The first one (A) is the questionnaires which asked about the use of Banjarese personal subject pronoun among the BKD and BHD speakers. It is in form of open-ended questionnaire. The rest two questionnaires (B and C) are ones which asked respondents to state their knowledge related to the use of Banjarese and American personal subject pronoun.

The data collection was conducted in September and November 2013 during the Odd Semester of 2013 / 2014 Academic Year. The individuals involved in collecting the data are the researchers themselves in order to ascertain that the data needed are feasibly obtained.

\section{Data Analysis}

The data from the questionnaire is analyzed by using simple descriptive statistics that is measures of central tendency (sum). Statistical analyses that include the thematic counts are conducted and the calculation is manually carried out. The data will be analyzed quantitatively, by counting the number of most chosen option, and qualitatively, by interpreting the numbers into words and concluding the responses on some open question items in the questionnaire. The presentation of the data is in form of tables and chart with the help of Microsoft Excel 2013.

\section{RESULTS AND DiSCUSSION}


This part presents the results from the data collection and the interpretation of the findings. All the data gathered are tabulated and simplified in some tables and analyzed simultaneously. It starts from the presentation of both languages' use of the $1^{\text {st }}, 2^{\text {nd }}$, and $3^{\text {rd }}$ personal subject pronoun. The analysis based on the findings follows afterward.

\section{A. The Use of American English Personal Subject Pronoun and Its Politeness}

Pronoun is used quite often whether in oral or written form of communication in English. The use of various pronouns needs a concern because there might be a condition which some people are unable to use the pronouns appropriately. The findings on the use of the American English personal subject pronouns are presented in Table 2 below.

TABLE 2

THE CORRECTLY-AND-INCORRECTLY-ANSWERED RESPONSES RELATED TO THE USE OF AMERICAN ENGLISH PERSONAL SUBJECT PRONOUN

\begin{tabular}{|c|c|c|c|c|}
\hline \multicolumn{3}{|c|}{ The Personal Subject Pronouns } & $\begin{array}{l}\text { The Number of Correct } \\
\text { Responses }\end{array}$ & $\begin{array}{l}\text { The Number of Incorrect } \\
\text { Responses }\end{array}$ \\
\hline \multirow{7}{*}{$\begin{array}{l}\text { The } 1^{\text {st }}, 2^{\text {nd }} \text {, and } 3^{\text {rd }} \text { Personal } \\
\text { Subject Pronoun }\end{array}$} & \multirow[t]{2}{*}{$1^{\text {st }}$} & I & 40 & 0 \\
\hline & & $\mathrm{We}$ & 9 & 31 \\
\hline & $2^{\text {nd }}$ & You & 30 & 10 \\
\hline & \multirow[t]{4}{*}{$3^{\text {rd }}$} & $\mathrm{He}$ & 35 & 5 \\
\hline & & She & 35 & 5 \\
\hline & & It & 30 & 10 \\
\hline & & They & 12 & 28 \\
\hline \multirow{8}{*}{$\begin{array}{l}\text { The Singular and Plural } \\
\text { Personal Subject Pronoun }\end{array}$} & \multirow[t]{5}{*}{ Singular } & $\mathrm{I}$ & 40 & 0 \\
\hline & & You & 21 & 19 \\
\hline & & $\mathrm{He}$ & 39 & 1 \\
\hline & & She & 37 & 3 \\
\hline & & It & 35 & 5 \\
\hline & \multirow[t]{3}{*}{ Plural } & $\mathrm{We}$ & 34 & 6 \\
\hline & & They & 36 & 4 \\
\hline & & You & 16 & 24 \\
\hline
\end{tabular}

Based on the data presented in Table 2 , it can be seen that only the $1^{\text {st }}$ personal pronoun which is correctly mentioned by all respondents. Other pronouns might still bring confusion to the students / respondents. Based on the result of the questionnaire (A), some students did not have a clear knowledge on distinguishing between the $1^{\text {st }}, 2^{\text {nd }}$, and $3^{\text {rd }}$ Personal Subject Pronouns. It can be seen that out of 40 respondents, only 9 persons answered the questions related to determining the English $1^{\text {st }}$ plural personal subject pronoun we correctly. Similarly, pronoun they only gets 12 respondents who answered the question about it correctly. On the contrary, plural pronoun you is not quite recognized by the students because more respondents incorrectly determined it as a plural form. It is a similar case with pronouns we and they.

In relation with the politeness, the situation, the degree of intimacy, the marital status, the occupation, the age and the sex are predicted to be the factors that might differentiate the use of the personal subject pronoun. However, in American English, and probably other varieties of English like British and Singaporean, does not distinguish the use of its pronoun in terms of politeness. The data on the use of American English personal subject pronoun related to the respondents' knowledge does not show a satisfying results seeing from a few point of view as the number is precisely shown in Table 3.

TABLE 3.

THE USE OF AMERICAN ENGLISH PERSONAL SUBJECT PRONOUN IN TERMS OF POLITENESS

\begin{tabular}{|l|l|l|}
\hline Points to Ponder & Yes & No \\
\hline English Personal Subject Pronoun and Official / Unofficial Situation & 11 & 29 \\
\hline English Personal Subject Pronoun and the Degree of Intimacy & 9 & 31 \\
\hline English Personal Subject Pronoun and Marital Status & 7 & 33 \\
\hline English Personal Subject Pronoun and Occupation & 7 & 33 \\
\hline English Personal Subject Pronoun and the Age & 9 & 31 \\
\hline English Personal Subject Pronoun and the Sex & 24 & 16 \\
\hline
\end{tabular}

There are 11 students who think that the American English personal subject pronouns are used differently in official and unofficial situations. In terms of degree of intimacy, marital status, occupation and age, the understanding is better because less than $25 \%$ of the respondents believe that there are different pronouns used when those points are involved. Therefore, such belief -or guess- is not correct because the use of the American English personal subject pronouns does not differentiate those aspects or points. There is a slight relief that more than half of the respondents understand that the American English personal subject pronoun stress on the importance of sex consideration or gender oriented. Although not all pronouns are reflecting the specific description of a gender, students' correct understanding on the different use of he, she and it might already help them in using English. Unfortunately, there are 16 students who are not conscious that sex categorization exists in English pronoun use.

\section{B. The Use of Banjarese Personal Subject Pronoun with Both Dialects and Its Politeness}


The discussion about the Banjerese Personal Subject Pronoun use is a little bit on whether both speakers of BKD and BHD differ in utilizing the pronouns. Moreover, the use of pronouns are then related to the politeness issue in terms of choice or preference. The reason or background of choosing or preferring certain terms becomes the analysis of each finding.

1. Official Situation

In official situations (forum/ discussion and classroom), a few speakers of BKD and BHD differentiate the use of $1^{\text {st }}$ and $2^{\text {nd }}$ personal subject pronoun. They occasionally use ulun (I) and pian (you), and at other times they use $a k u$ (I) and $i k a m$ (you). As for the $2^{\text {nd }}$ personal subject pronoun, bapak (Mr./Sir) and $i b u$ (Mrs./Madam)are also used. The $3^{\text {rd }}$ personal subject pronoun used by both speakers for a respected person in official situation is $\operatorname{sidin}$ (s/he). The most $1^{\text {st }}$ personal subject pronoun used is ulun (I). It means that speakers of both dialects have similar sense of appropriateness in choosing the pronoun whether it is in a formal forum and discussion or in the contexts of classroom. The same findings also appear in terms of Banjarese $2^{\text {nd }}$ and $3^{\text {rd }}$ personal subject pronoun (Table 4).

Referring to the findings in Table 4, Pian and sidin have been chosen the most by the respondents. The use ulun, pian and sidin in an official situation reflects that although the participants or the speakers are of various age and gender, they prefer to choose the most polite form of Banjarese personal subject pronoun. The context or the situation determine the choice of pronoun by the Banjarese speakers with BKD and BHD. In other words, the politeness use of the pronouns has been regulated more by the official situation regardless other considerations like the age and the gender.

TABLE 4.

The SuMmary of BANJARESE PERSONAL SUBJECT PRONOUN USE IN OFFICIAL SituATION

\begin{tabular}{|c|c|c|c|c|c|}
\hline \multirow{2}{*}{\multicolumn{2}{|c|}{ OFFICIAL SITUATION }} & \multicolumn{2}{|l|}{ BKD (37) } & \multicolumn{2}{|l|}{ BHD (24) } \\
\hline & & \multirow{2}{*}{$\begin{array}{l}\text { PERSONAL } \\
\text { SUBJECT } \\
\text { PRONOUN } \\
\text { ulun, pian }\end{array}$} & \multirow{2}{*}{$\begin{array}{l}\text { TOTAL } \\
27\end{array}$} & \multirow{2}{*}{$\begin{array}{l}\text { PERSONAL } \\
\text { SUBJECT } \\
\text { PRONOUN } \\
\text { ulun, pian }\end{array}$} & \multirow{2}{*}{$\begin{array}{l}\text { TOTAL } \\
20\end{array}$} \\
\hline \multirow{4}{*}{$\begin{array}{l}\text { 1st and } 2 \text { nd Personal } \\
\text { Subject Pronoun }\end{array}$} & \multirow[t]{4}{*}{ In a forum / discussion } & & & & \\
\hline & & aku, ikam & 7 & aku, ikam & 3 \\
\hline & & ane, agan & 1 & No answer & 1 \\
\hline & & No answer & 2 & & \\
\hline \multirow{3}{*}{$\begin{array}{l}\text { 2nd Personal Subject } \\
\text { Pronoun }\end{array}$} & \multirow[t]{3}{*}{ In the classroom } & pian & 34 & pian & 22 \\
\hline & & bapak, ibu & 2 & bapak, ibu & 2 \\
\hline & & No answer & 1 & & \\
\hline \multirow{2}{*}{$\begin{array}{l}\text { 3rd Personal Subject } \\
\text { Pronoun }\end{array}$} & \multirow{2}{*}{$\begin{array}{l}\text { Respected person in } \\
\text { official context }\end{array}$} & sidin & 37 & sidin & 23 \\
\hline & & & & nama & 1 \\
\hline
\end{tabular}

\section{b. Unofficial Situation}

Outside the classroom, the $1^{\text {st }}$ and $2^{\text {nd }}$ personal subject pronoun which is mostly used is ulun and pian. In unofficial situation like this, the respondents consider that it is still important to maintain the politeness when talking to the lectures as the respected person although it is outside the classroom. BKD and BHD speakers agree that using Ulun (I) and pian (you)as the $1^{\text {st }}$ and $2^{\text {nd }}$ personal subject pronoun is applicable in a conversation with an informal situation and respectable interlocutor. The pronoun saya (I), which belongs to Indonesian language, and the terms of address $i b u$ (Mrs./Mam)and bapak (Mr./Sir) are used by two respondents. This might be because they wanted to stress on the importance of showing respect to the interlocutor like in a formal or official context (Table 5). There is one respondent stated that she or he uses saya when speaking to the lecturer outside the classroom. Perhaps, she or he does it for the sake of maintaining the formality relationship between a student and a lecturer since saya is not a Banjarese $1^{\text {st }}$ personal subject pronoun.

TABLE 5.

The Summary of B ANJARESE PERSONAL SubJECT PRONOUN USE IN UNOFFICIAL SituATION

\begin{tabular}{|c|c|c|c|c|c|}
\hline \multirow{2}{*}{\multicolumn{2}{|c|}{ UNOFFICIAL SITUATION }} & \multicolumn{2}{|l|}{ BKD (37) } & \multicolumn{2}{|l|}{ BHD (24) } \\
\hline & & \multirow{2}{*}{$\begin{array}{l}\text { PERSONAL SUBJECT } \\
\text { PRONOUN } \\
\text { ulun, pian }\end{array}$} & \multirow{2}{*}{$\begin{array}{l}\text { TOTAL } \\
33\end{array}$} & \multirow{2}{*}{$\begin{array}{l}\text { PERSONAL } \\
\text { SUBJECT } \\
\text { PRONOUN } \\
\text { ulun, pian }\end{array}$} & \multirow{2}{*}{$\begin{array}{l}\text { TOTAL } \\
24\end{array}$} \\
\hline \multirow{4}{*}{$\begin{array}{l}\text { 1st and } 2 \text { nd Personal } \\
\text { Subject Pronoun }\end{array}$} & \multirow{4}{*}{$\begin{array}{l}\text { Outside the } \\
\text { classroom }\end{array}$} & & & & \\
\hline & & saya & 1 & & \\
\hline & & ibu, bapak & 1 & & \\
\hline & & No answer & 2 & & \\
\hline
\end{tabular}

c. Degree of Intimacy

When talking to a special or intimate person, both Banjarese speakers of BKD and BHD used the polite choice of $1^{\text {st }}$ and $2^{\text {nd }}$ personal subject pronoun -ulun (I) and pian (you) - the most. The tendency is that the speakers used the pronouns because they want to show the feeling of being close to each other. In addition, the need of showing respect and love feeling is expressed by the use of the pronouns. Aku (I) and ikam (you) are used by 14 persons out of 61 total 61 respondents. These pronouns are probably is use because the couples are of the same age that they speak the language at the same level of politeness. Interestingly, the rudest form of $1^{\text {st }}$ and $2^{\text {nd }}$ personal subject pronouns unda (I) 
and nyawa (you) are in use between lovebirds or spouses. In this context, unda (I) and nyawa (you) are not considered rude anymore, but it is more to a habit in the couples' daily interaction.

The finding on love-mate is a lot different with the one for personal subject pronoun used between close friends. Aku (I) and ikam (you) are pronouns which are mostly used by both speakers of BKD and BHD. The usage of this second level pronoun might be due to the equal position or condition of the users. They are probably about the same age, origin, background or interest. Unda and nyawa are in the second place for BKD speakers while Ulun (I) and pian (you)are by BHD speakers for the same rank in use. Slang terms like imak and auk are also found among close friends.

Ulun (I) and pian (you)are conventionally used by almost all speakers of BKD and BHD. Strangely though, there is a respondent from BKD admitted using aku (I) and ikam (you) when interacting with their parents just like unda (I) and nyawa (you) used between close friends. Once again, this usage is not intended of being rude, but it more of a habit between the speakers. Terms of address abah (father) and mama (mother) are also functioned as the $1^{\text {st }}$ and $2^{\text {nd }}$ personal subject pronoun. Among siblings, the most frequents pronouns used are $a k u$ (I) and ikam (you). However, the total number is not dominant, only $54 \%$ for BKD speakers and $50 \%$ for BHD ones. Ulun (I) and pian (you)are also used by the speakers covering $40 \%$ and $37.5 \%$ of the total respondents from BKD and BHD speakers. This finding is might be due to the consideration of age difference between siblings. The date are presented in Table 4.5a below.

TABLE 6.

The Summary of B ANJARESE 1ST AND 2ND PeRsonal SubJeCt PRONOUN UsE IN CONSIDERING THE DEGREE OF INTIMACY

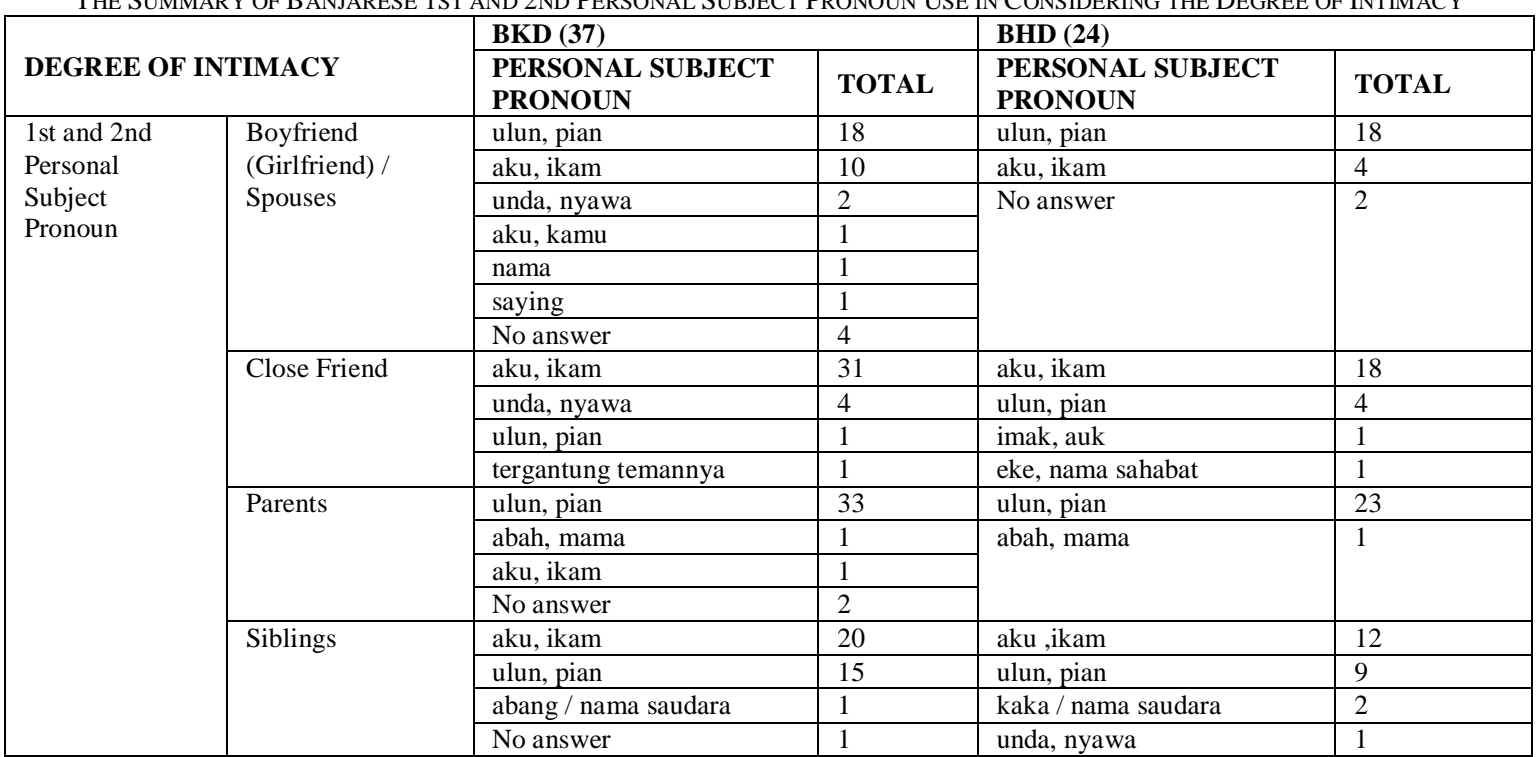

The findings on the use of $3^{\text {rd }}$ personal subjective pronouns of Banjarese speakers of BKD and BHD show that inya is very common among boyfriend/girlfriends, spouses, close friends, and siblings. For parents, the pronoun sidin (s/he) is used dominantly although there is terms of address used like mama (mother) and abah (father) or mamaku (my mother) and abahku (my father). This reflects that the use of inya and sidin (both refer to 's/he') really depends on whom the person being talked about is (Table 7). 
TABLE 7.

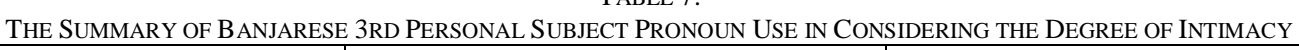

\begin{tabular}{|c|c|c|c|c|c|}
\hline \multirow{3}{*}{\multicolumn{2}{|c|}{ DEGREE OF INTIMACY }} & \multicolumn{2}{|l|}{ BKD (37) } & \multirow{2}{*}{\multicolumn{2}{|c|}{ BHD (24) }} \\
\hline & & \multirow{3}{*}{$\begin{array}{l}\text { PERSONAL SUBJECT } \\
\text { PRONOUN } \\
\text { inya } \\
\end{array}$} & \multirow{3}{*}{$\begin{array}{l}\text { TOTAL } \\
23\end{array}$} & & \multirow{3}{*}{$\begin{array}{l}\text { TOTAL } \\
19 \\
\end{array}$} \\
\hline & & & & \multirow{2}{*}{$\begin{array}{l}\text { PERSONAL } \\
\text { SUBJECT PRONOUN } \\
\text { inya }\end{array}$} & \\
\hline \multirow{19}{*}{$\begin{array}{l}\text { 3rd Personal } \\
\text { Subject } \\
\text { Pronoun }\end{array}$} & \multirow{5}{*}{$\begin{array}{l}\text { Boyfriend } \\
\text { (Girlfriend) / } \\
\text { Spouses }\end{array}$} & & & & \\
\hline & & sidin & 9 & \multirow{4}{*}{$\begin{array}{l}\text { sidin } \\
\text { No answer }\end{array}$} & 3 \\
\hline & & beliau & 1 & & \multirow[t]{3}{*}{2} \\
\hline & & nama & 1 & & \\
\hline & & No answer & 3 & & \\
\hline & \multirow[t]{4}{*}{ Close Friend } & inya & 33 & inya & 22 \\
\hline & & sidin & 1 & \multirow[t]{3}{*}{ by name } & \multirow[t]{3}{*}{2} \\
\hline & & beliau & 1 & & \\
\hline & & No answer & 2 & & \\
\hline & \multirow[t]{5}{*}{ Parents } & sidin & 32 & sidin & 21 \\
\hline & & mamaku, abahku & 2 & mamaku, abahku & 2 \\
\hline & & mama, abah & 1 & \multirow[t]{3}{*}{ mama, abah } & \multirow[t]{2}{*}{1} \\
\hline & & ibu & 1 & & \\
\hline & & No answer & 1 & & \\
\hline & \multirow[t]{5}{*}{ Siblings } & inya & 30 & inya & 17 \\
\hline & & sidin & 3 & sidin & 3 \\
\hline & & kakaku & 2 & sidin, inya & 1 \\
\hline & & beliau & 1 & kaka, adding & 1 \\
\hline & & No answer & 1 & by name & 2 \\
\hline
\end{tabular}

d. Social Status

Ulun (I) and pian (you)are the most personal subject pronoun used either by considering marital status or occupation of the interlocutors. It seems that BKD and BHD speakers prioritize the use of this most polite form of Banjarese pronoun when speaking to a person whom they know or do not have the knowledge of the marital status and occupation (Table 8). In the case of marital status, there usually is an assumption that someone who has married is already mature and get more respect although sometimes she or he is still very young. As for the job, talking to a person who has worked might also be different in politeness because someone who has had a job is considered more experienced.

The use of $a k u$ and $i k a m$ is in the second place by the BKD and BHD speakers. This might be possible in the situation where the speakers are in the same level, for example having similar prestigious job or having more or less similar length of marriage years. Related to marital status and occupation of the $3^{\text {rd }}$ person being talked about, the use of sidin and inya (he, she) is very common among the speakers of BKD and BHD. Even when the speakers do not know the marital status, they use sidin and inya interchangeably.

TABLE 8.

THE SuMmary OF BANJARESE PERSONAL SUBJeCt PRONOUN USE IN CONSIDERING THE SOCIAL STATUS

\begin{tabular}{|c|c|c|c|c|c|}
\hline \multirow{2}{*}{\multicolumn{2}{|c|}{ SOCIAL STATUS }} & \multicolumn{2}{|l|}{ BKD (37) } & \multicolumn{2}{|l|}{ BHD (24) } \\
\hline & & \multirow{2}{*}{$\begin{array}{l}\text { PERSONAL SUBJECT } \\
\text { PRONOUN } \\
\text { ulun, } \\
\end{array}$} & \multirow{2}{*}{$\begin{array}{l}\text { TOTAL } \\
28 \\
\end{array}$} & \multirow{2}{*}{$\begin{array}{l}\text { PERSONAL SUBJECT } \\
\text { PRONOUN } \\
\text { ulun, pian } \\
\end{array}$} & \multirow{2}{*}{$\begin{array}{l}\text { TOTAL } \\
17 \\
\end{array}$} \\
\hline \multirow{18}{*}{$\begin{array}{l}\text { 1st and 2nd } \\
\text { Personal } \\
\text { Subject } \\
\text { Pronoun }\end{array}$} & \multirow{5}{*}{$\begin{array}{l}\text { Unknown Marital } \\
\text { Status }\end{array}$} & & & & \\
\hline & & aku, ikam & 5 & \multirow{4}{*}{$\begin{array}{l}\text { aku, ikam } \\
\text { depends on age }\end{array}$} & 6 \\
\hline & & aku, kamu & 1 & & \multirow[t]{3}{*}{1} \\
\hline & & mas, mbak & 1 & & \\
\hline & & No answer & 2 & & \\
\hline & \multirow{4}{*}{$\begin{array}{l}\text { Known Marital } \\
\text { Status }\end{array}$} & ulun, pian & 31 & ulun, pian & 20 \\
\hline & & aku, ikam & 3 & & 3 \\
\hline & & bapak, ibu & 1 & \multirow{2}{*}{ depends on age } & \multirow[t]{2}{*}{1} \\
\hline & & No answer & 2 & & \\
\hline & \multirow[t]{5}{*}{ Unknown Job } & ulun, pian & 26 & ulun, pian & 17 \\
\hline & & aku, ikam & 7 & & 6 \\
\hline & & kamu & 1 & \multirow{3}{*}{ depends on age } & \multirow[t]{3}{*}{1} \\
\hline & & bapak, ibu, mas, mbak & 1 & & \\
\hline & & No answer & 2 & & \\
\hline & \multirow[t]{4}{*}{ Known Job } & ulun, pian & 30 & ulun, pian & 20 \\
\hline & & aku, ikam & 4 & aku, ikam & 3 \\
\hline & & bapak, ibu & 1 & \multirow[t]{2}{*}{ depends on age } & \multirow[t]{2}{*}{1} \\
\hline & & No answer & 2 & & \\
\hline \multirow{8}{*}{$\begin{array}{l}\text { rd Personal } \\
\text { Subject } \\
\text { Pronoun }\end{array}$} & \multirow{4}{*}{$\begin{array}{l}\text { Unknown Marital } \\
\text { Status }\end{array}$} & sidin & 20 & sidin & 13 \\
\hline & & inya & 14 & \multirow[t]{3}{*}{ inya } & \multirow[t]{3}{*}{11} \\
\hline & & inya, sidin & 1 & & \\
\hline & & No answer & 2 & & \\
\hline & \multirow[t]{4}{*}{ Unknown Job } & sidin & 19 & sidin & 13 \\
\hline & & inya & 15 & \multirow[t]{3}{*}{ inya } & \multirow[t]{3}{*}{11} \\
\hline & & sidin, inya & 1 & & \\
\hline & & No answer & 2 & & \\
\hline
\end{tabular}


e. Age

Almost all of the respondents admitted that they use $a k u$ and ikam frequently when talking to friends, siblings and new acquaintances who are similar age and younger. Ulun (I) and pian (you)are used when communicating with older friends, siblings and new acquaintances. Unda (I) and nyawa (you) are also used by a few respondents. It seems that these last two pronouns are very commong among people who are more or less the same age or younger. However, there is a finding that someone still uses unda and nyawa although s/he is talking to friends, siblings and new acquaintances who are older. This might be due to the habit of using this $3^{\text {rd }}$ level of pronoun. As a result, regardless the age of the interlocutors, that person still uses unda and nyawa. Therefore, aku (I) and ikam (you) are the most favorable ones because they bring neutrality among friends, siblings and new acquaintances.

There is an interesting point from BHD speaker. A respondent admitted that even though s/he talks with friend with similar age, s/he uses the $1^{\text {st }}$ and $2^{\text {nd }}$ personal subject pronouns ulun (I), pian (you). The reason maybe that person wants to sound polite and respect the interlocutors. When talking about someone who is older, most of the respondents agreed that they use sidin. However, there are some person stated that they could use inya to someone who older. This might be due to their habit. Furthermore, it is because that someone older is not quite respectable. As a matter of fact, the colleagues just refer him / her by the $2^{\text {nd }}$ level of $3^{\text {rd }}$ personal subject pronoun in Banjerese -inya. On the contrary, the result shows that someone who is younger might be referred by sidin by some people. It may happens because that someone younger probably has a good position in the community. For example, he is the new leader of a party or the young director of a company.

Someone older is usually referred as sidin, and someone younger is denoted with inya (Table 9). This data supports that age has a role in determining whether a speaker of BKD or BHD speak with the first or the second level of pronoun politeness in Banjarese. The case of sidin being used for someone younger is an exception which the speaker only wants to sound polite and respectful to the third person being talked about or because the person is of higher position.

TABLE 9.

THE Summary of B ANJARESE PERSONAL SubJECT PRONOUN USE In CONSIDERING THE AgE

\begin{tabular}{|c|c|c|c|c|c|}
\hline \multirow{2}{*}{\multicolumn{2}{|c|}{ AGE }} & \multicolumn{2}{|l|}{ BKD (37) } & \multicolumn{2}{|l|}{ BHD (24) } \\
\hline & & $\begin{array}{l}\text { PERSONAL SUBJECT } \\
\text { PRONOUN }\end{array}$ & TOTAL & $\begin{array}{l}\text { PERSONAL SUBJECT } \\
\text { PRONOUN }\end{array}$ & TOTAL \\
\hline \multirow{27}{*}{$\begin{array}{l}\text { 1st and } 2 \mathrm{nd} \\
\text { Personal Subject } \\
\text { Pronoun }\end{array}$} & \multirow{4}{*}{$\begin{array}{l}\text { Friend with Similar } \\
\text { Age }\end{array}$} & aku, ikam & 32 & aku, ikam & 21 \\
\hline & & unda, nyawa & 3 & unda, nyawa & 1 \\
\hline & & menyebut nama & 1 & ulun, pian & 1 \\
\hline & & tergantung temannya & 1 & No answer & 1 \\
\hline & \multirow[t]{3}{*}{ Friend who is older } & ulun, pian & 23 & ulun, pian & 20 \\
\hline & & \multirow[t]{2}{*}{ aku, ikam } & \multirow[t]{2}{*}{14} & aku, ikam & 3 \\
\hline & & & & unda, nyawa & 1 \\
\hline & \multirow{3}{*}{$\begin{array}{l}\text { Friend who is } \\
\text { younger }\end{array}$} & aku, ikam & 35 & aku, ikam & 15 \\
\hline & & ulun, pian & 1 & ulun, pian & 8 \\
\hline & & nama, kamu & 1 & unda, nyawa & 1 \\
\hline & \multirow{3}{*}{$\begin{array}{l}\text { Sibling with } \\
\text { Similar Age }\end{array}$} & aku, ikam & 33 & aku, ikam & 19 \\
\hline & & unda, nyawa & 2 & ulun, pian & 4 \\
\hline & & nama & 2 & unda, nyawa & 1 \\
\hline & \multirow{3}{*}{$\begin{array}{l}\text { Sibling who is } \\
\text { older }\end{array}$} & ulun, pian & 30 & ulun, pian & 18 \\
\hline & & aku, ikam & 6 & aku, ikam & 5 \\
\hline & & nama & 1 & unda, nyawa & 1 \\
\hline & \multirow{5}{*}{$\begin{array}{l}\text { Sibling who is } \\
\text { younger }\end{array}$} & aku, ikam & 27 & aku, ikam & 15 \\
\hline & & ulun, pian & 5 & ulun, pian & 8 \\
\hline & & nama & 3 & \multirow[t]{3}{*}{ unda, nyawa } & \multirow[t]{3}{*}{1} \\
\hline & & abang & 1 & & \\
\hline & & unda, nyawa & 1 & & \\
\hline & \multirow{3}{*}{$\begin{array}{l}\text { New acquaintance } \\
\text { who is older }\end{array}$} & ulun, pian & 35 & ulun, pian & 23 \\
\hline & & unda, nyawa & 1 & \multirow[t]{2}{*}{ unda, nyawa } & \multirow[t]{2}{*}{1} \\
\hline & & $\begin{array}{l}\text { tergantung umur, menyebut } \\
\text { nama }\end{array}$ & 1 & & \\
\hline & \multirow{3}{*}{$\begin{array}{l}\text { New acquaintance } \\
\text { who is younger }\end{array}$} & aku, ikam & 21 & ulun, pian & 18 \\
\hline & & ulun, pian & 15 & \multirow[t]{2}{*}{ aku, ikam } & \multirow[t]{2}{*}{5} \\
\hline & & No answer & 1 & & \\
\hline \multirow{4}{*}{$\begin{array}{l}\text { 3rd Personal } \\
\text { Subject Pronoun }\end{array}$} & \multirow[t]{2}{*}{ Someone older } & sidin & 31 & sidin & 21 \\
\hline & & inya & 6 & inya & 3 \\
\hline & \multirow[t]{2}{*}{ Someone younger } & inya & 31 & inya & 22 \\
\hline & & sidin & 2 & sidin & 2 \\
\hline
\end{tabular}

\section{f. Sex Distinction}

Interestingly, more respondents used $a k u$, ikam rather than other pronouns. In terms of sex or gender, both male and female of the BHD and BKD speakers use the pronouns aku and ikam the most. This might be because $a k u$ and $i k a m$ sounds more neutral when talking across genders. When it comes to similar sex conversation, the male and female speakers tend to use unda and nyawa. This is probably triggered by the condition that the speakers belong to the same gender and they feel more comfortable using the $3^{\text {rd }}$ level of Banjarese $1^{\text {st }}$ and $2^{\text {nd }}$ personal subject pronoun. A 
respondent said that he used the terms like bro, man, coy, dude in their daily conversation. It is probably caused by the same gender that he and the interlocutor belong to. In other words, it is because they are men.

TABLE 10.

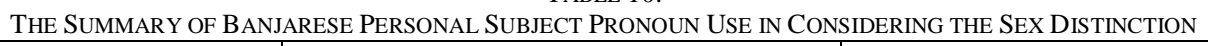

\begin{tabular}{|c|c|c|c|c|c|}
\hline \multirow{2}{*}{\multicolumn{2}{|c|}{ SEX DISTINCTION }} & \multicolumn{2}{|l|}{ BKD (37) } & \multicolumn{2}{|l|}{ BHD (24) } \\
\hline & & $\begin{array}{l}\text { PERSONAL SUBJECT } \\
\text { PRONOUN }\end{array}$ & TOTAL & $\begin{array}{l}\text { PERSONAL } \\
\text { SUBJECT PRONOUN }\end{array}$ & TOTAL \\
\hline \multirow{10}{*}{$\begin{array}{l}\text { 1st and 2nd Personal } \\
\text { Subject Pronoun }\end{array}$} & \multirow[t]{5}{*}{ Male } & aku, ikam & 30 & aku, ikam & 17 \\
\hline & & aku,ikam and unda,nyawa & 2 & ulun, pian and aku,ikam & 1 \\
\hline & & ulun, pian & 1 & depends on the age & 1 \\
\hline & & depends on the age & 1 & \multirow[t]{2}{*}{ unda, nyawa } & \multirow[t]{2}{*}{1} \\
\hline & & by name & 1 & & \\
\hline & \multirow[t]{5}{*}{ Female } & aku, ikam & 29 & aku, ikam & 15 \\
\hline & & ulun, pian & 2 & ulun, pian & 5 \\
\hline & & unda, nyawa & 2 & depends on the age & 2 \\
\hline & & aku,ikam and unda,nyawa & 2 & \multirow[t]{2}{*}{ ulun, pian and aku,ikam } & \multirow[t]{2}{*}{2} \\
\hline & & depends on the age & 1 & & \\
\hline
\end{tabular}

g. Others

The terms kita ini, saurang ini, and yayang ini, as it can be seen in Table 4.9, are also used by the Banjarese speakers of BKD and BHD. Kita ini and Saurang ini is applied in the context of casual conversations. Kita ini refer to the speaker oneself when it sounds inappropriate to use the term ulun, aku or unda. For example when that person is talking to a stranger whom s/he meets at a public place. It is more often heard used by men than by women. Saurang ini is often used when a person talks about himself or herself. The slang terms like auk and imak is still surprisingly used among the youth. These expressions are quite similar with Bahasa Walikan used by Malangese people (those who are from Malang, East Java). Another interesting finding is that the people also use ana and ente which are adopted from Arabic. Although the terms are not Banjarese, but they are used among young people who are originally the native speakers of Banjarese.

TABLE 11

THE SuMMARY OF OTHER BANJARESE PERSONAL SUBJECT PRONOUN USE

\begin{tabular}{|l|l|l|}
\hline OTHERS & kita ini & MEANING \\
\hline \multirow{4}{*}{$1^{\text {st }}$ Personal Subject Pronoun } & saurang ini & I \\
\cline { 2 - 3 } & yayang ini & I \\
\cline { 2 - 3 } & imak & I \\
\cline { 2 - 3 } & ana & I \\
\hline $22^{\text {nd }}$ Personal Subject Pronoun & auk & I \\
\cline { 2 - 3 } & ente & You (singular) \\
\cline { 2 - 3 } & buhan pian & You (singular) \\
\cline { 2 - 3 } & buhan ikam & You (plural) \\
\cline { 2 - 3 } & buhan nyawa & You (plural) \\
\hline \multirow{3}{*}{$3^{\text {rd }}$ Personal Subject Pronoun } & nang ini & You (plural) \\
\cline { 2 - 3 } & nang itu & It \\
\hline
\end{tabular}

Indirectness also happens in Banjarese use of its personal subject pronoun. Instead of using the direct $2^{\text {nd }}$ personal subject pronoun, the speaker change it into a term of address Bapak as it in this example:

Mun pian hakun, kita kawa ay mulai langsung.

(If you agree, we can start right away)

The speaker might switch the sentence into:

Mun Bapak hakun, kita kawa ay langsung mulai.

(If you agree, we can start right away)

The reason of switching the personal pronoun into term of address like this is probably due to the intention of showing more deference. As a result, the most polite Banjarese personal pronoun pian is not enough to show the respect.

\section{CONCLUSiON}

The choice on the use of the pronouns is sometimes not rigidly strict to the existing patterns. It is more determined by the relationship of the speakers in a given context. Although unda and nyawa is the most rude form of pronoun in Banjarese, in some familiar contexts they might be used without any feeling of rudeness anymore. It becomes usual between friends, the terms used is considered as not rude. When people used the $3^{\text {rd }}$ level of politeness of Banjarese, it does not mean that they are impolite. It happens when they feel that they are close enough to the interlocutors. 
The politeness that happens in Banjarese when its speakers use personal subject pronoun is the switch of its use as in the case of ulun, pian which is customarily used when speaking with someone older, respectable and more superior. Ulun, pian, in particular occasions, can be used when talking with someone younger and inferior due to certain reasons, for example to accustom children in order that they speak using the most polite form of Banjarese personal subject pronoun.

The languages' pronouns -Banjarese and American English- are based on singular and plural distinction. However, Banjarese does not have a gender distinction as in the American English. Both Banjarese and American English personal pronouns are categorised into three persons: first person, second person and third person. However, English personal pronouns are depend mostly on the grammatical role while banjarese personal pronouns can indicate the social status or the relation of the speaker and other persons in the discourse. Personal pronouns play an important play in communication, especially in Banjarese. They can reveal the social status or the relationship between the speaker and the listener, in some cases, they can also show the politeness or impoliteness of the speakers.

Despite the limitation of this study, there are some other points to ponder which might be useful to conduct in the next study. First, there might be other Banjarese pronouns which have not been discovered in this research. Second, in the future research, it is suggested that the male and female respondents are separated in order that a convincing conclusion about the influence of gender can be more stressed out. Last, there should be another investigation on the respondents who are not dominant to only a particular dialect, either BKD or BBDK. They might have a mix of both dialects because they experience living in particular areas where the community at certain times is BKD prevailing and at other times is BKD dominant.

\section{APPENDIX A}

It is a questionnaire on the use of language in which it aims to determine the pronoun used when communicating in Bahasa Banjar differentiated by the subjects dialects of Banjar Hulu and Banjar Kuala. 
ANGKET PEMAKAIAN BAHASA (A)

Penelitian ini bertujuan untuk mengetahui kata ganti yang dipakai ketika berkomunikasi dalam Bahasa Banjar. Tolong isikan angket berikut sesuai dengan data yang sebenarnya. Terima kasih atas kerjasamanya

1. Jenis Kelamin : Laki-laki/Perempuan *)

2. Daerah asal

3. Tempat Lahir

4. Bahasa Banjar apa yang dominan anda gunakan dalam percakapan sehari-hari:

a. Bahasa Banjar Dialek Hulu (BBDH)

b. Bahasa Banjar Dialek Kuala (BBDK)

Bila anda tidak yakin, untuk mengetahui apakah anda dominan BBDH atau BBDK silahkan lingkari salah satu kata yang sering anda gunakan dalam berbahasa Banjar dari dua pilihan yang diberikan berikut:

\begin{tabular}{|l|l|}
\hline kawa & hingkat \\
\hline lelongkang & lalungkang \\
\hline catuk & tutui \\
\hline ampih & tajua \\
\hline
\end{tabular}

\begin{tabular}{|l|l|}
\hline kawan & kawal \\
\hline gasan & hagan \\
\hline dapur & padu \\
\hline amang/paman & acil laki \\
\hline
\end{tabular}

\begin{tabular}{|l|l|}
\hline cocok & cucuk \\
\hline bajauh & baugah \\
\hline kayi & nini laki \\
\hline hanyar & puga \\
\hline
\end{tabular}

5. Apa yang anda gunakan ketika harus berbicara di forum / diskusi dalam bahasa Banjar?
a. ulun, pian
b. aku, ikam
c. unda, nyawa
d. lainya (sebutkan)

6. Bagaimana anda menyebut guru / dosen dalam Bahasa Banjar ketika berbicara di dalam kelas?
a. pian
b. ikam
c. nyawa
d. lainya (sebutkan)

7. Apa yang anda gunakan untuk menyebut dosen ketika ketika anda sedang membicarakan tentang dosen dengan orang lain dalam Bahasa Banjar?
a. sidin
b. inya
c. lainya (sebutkan)

8. Kata ganti apa yang anda gunakan ketika berbicara dengan dosen di luar kelas?
a. ulun, pian
b. aku, ikam
c. unda, nyawa
d. lainya (sebutkan)

9. Apa yang anda gunakan ketika berbicara dengan pacar/ istri/suami dalam Bahasa Banjar?
a. ulun, pian
b. aku, ikam
c. unda, nyawa
d. lainya (sebutkan)

10. Apa yang anda gunakan ketika berbicara dengan sahabat dekat anda dalam Bahasa Banjar?
a. ulun, pian
b. aku, ikam
c. unda, nyawa
d. lainya (sebutkan)

11. Apa yang anda gunakan ketika berbicara dengan orang tua dalam Bahasa Banjar?
a. ulun, pian
b. aku, ikam
c. unda, nyawa
d. lainya (sebutkan) 
12. Apa yang anda gunakan ketika berbicara dengan saudara dalam Bahasa Banjar?
a. ulun, pian
b. aku, ikam
c. unda, nyawa
d. lainya (sebutkan)

13. Apa yang anda gunakan untuk menyebut pacar/ istri/suami anda ketika ketika anda sedang membicarakannya dengan orang lain dalam Bahasa Banjar?
a. sidin
b. inya
c. lainya (sebutkan)

14. Apa yang anda gunakan untuk menyebut sahabat dekat anda ketika ketika anda sedang membicarakannya dengan orang lain dalam Bahasa Banjar?
a. sidin
b. inya
c. lainya (sebutkan)

15. Apa yang anda gunakan untuk menyebut orang tua anda ketika ketika anda sedang membicarakannya dengan orang lain dalam Bahasa Banjar?
a. sidin
b. inya
c. lainya (sebutkan)

16. Apa yang anda gunakan untuk menyebut saudara anda ketika ketika anda sedang membicarakannya dengan orang lain dalam Bahasa Banjar?
a. sidin
b. inya
c. lainya (sebutkan)

17. Apa yang anda gunakan ketika anda berbicara dengan orang yang anda tidak tahu status perkawinannya.
a. ulun, pian
b. aku, ikam
c. unda, nyawa
d. lainya (sebutkan)

18. Apa yang anda gunakan ketika anda berbicara dengan orang yang anda tahu status perkawinannya.
a. ulun, pian
b. aku, ikam
c. unda, nyawa
d. lainya (sebutkan)

19. Apa yang anda gunakan ketika anda berbicara dengan orang yang anda tidak tahu pekerjaannya?
a. ulun, pian
b. aku, ikam
c. unda, nyawa
d. lainya (sebutkan)

20. Apa yang anda gunakan ketika anda berbicara dengan orang yang anda tahu status pekerjaannya?
a. ulun, pian
b. aku, ikam
c. unda, nyawa
d. lainya (sebutkan)

21. Apa yang anda gunakan untuk menyebut orang lain yang anda tidak tahu status perkawinannya dalam Bahasa Banjar?
a. sidin
b. inya
c. lainya (sebutkan)

22. Apa yang anda gunakan untuk menyebut orang lain yang anda tidak tahu pekerjaanya dalam Bahasa Banjar?
a. sidin
b. inya
c. lainya (sebutkan)

23. Apa yang anda gunakan ketika berbicara dengan teman yang seumuran anda?
a. ulun, pian
b. aku, ikam
c. unda, nyawa
d. lainya (sebutkan) 
24. Apa yang anda gunakan ketika berbicara dengan teman yang lebih tua dari anda?
a. ulun, pian
b. aku, ikam
c. unda, nyawa
d. lainya (sebutkan)

25. Apa yang anda gunakan ketika berbicara dengan teman yang lebih muda dari anda?
a. ulun, pian
b. aku, ikam
c. unda, nyawa
d. lainya (sebutkan)

26. Apa yang anda gunakan ketika berbicara dengan saudara yang seumuran anda?
a. ulun, pian
b. aku, ikam
c. unda, nyawa
d. lainya (sebutkan)

27. Apa yang anda gunakan ketika berbicara dengan saudara yang lebih tua dari anda?
a. ulun, pian
b. aku, ikam
c. unda, nyawa
d. lainya (sebutkan)

28. Apa yang anda gunakan ketika berbicara dengan saudara yang lebih muda dari anda?
a. ulun, pian
b. aku, ikam
c. unda, nyawa
d. lainya (sebutkan)

29. Apa yang anda gunakan ketika berbicara dengan seseorang yang lebih tua, tapi baru anda kenal / tidak begitu anda kenal?
a. ulun, pian
b. aku, ikam
c. unda, nyawa
d. lainya (sebutkan)

30. Apa yang anda gunakan ketika berbicara dengan seseorang yang lebih tua, baru anda kenal / tidak begitu anda kenal
a. ulun, pian
b. aku, ikam
c. unda, nyawa
d. lainya (sebutkan)

31. Bagaimana anda menyebut orang yang lebih tua ketika sedang membicarakannya dalam Bahasa Banjar?
a. sdin
b. inya
c. lainya (sebutkan)

32. Bagaimana anda menyebut orang yang lebih muda ketika sedang membicarakannya dalam Bahasa Banjar?
a. sdin
b. inya
c. lainya (sebutkan)

33. Apa yang anda gunakan ketika berbicara lawan bicara laki-laki?
a. ulun, pian
b. aku, ikam
c. unda, nyawa
d. lainya (sebutkan)

34. Apa yang anda gunakan ketika berbicara lawan bicara perempuan?
a. ulun, pian
b. aku, ikam
c. unda, nyawa
d. lainya (sebutkan)

\section{TERIMA KASIH ATAS BANTUANNYA}

\section{APPENDIX B}

It is a questionnaire on the use of language in which it aims to determine the pronoun used when communicating in Bahasa Banjar by considering the formal and informal situation, intimacy level, marital status, age. sex, and context. 


\section{ANGKET PEMAKAIAN BAHASA}

Penelitian ini bertujuan untuk mengetahui kata ganti yang dipakai ketika berkomunikasi dalam Bahasa Banjar. Tolong isikan angket berikut sesuai dengan data yang sebenarnya. Terima kasih atas kerjasamanya.

1. Apakah situasi formal dan informal memberikan pengaruh dalam anda berbicara menggunakan Bahasa Banjar? Tolong jelaskan:

2. Apakah tingkat kedekatan anda dengan seseorang mempengaruhi cara anda memanggilnya? Tolong jelaskan:

3. Apakah status perkawinan dan pekerjaan menentukan tingkatan kesopanan cara berbicara anda? Tolong jelaskan:

4. Apakah umur lawan bicara menentukan cara anda memanggilnya? Tolong jelaskan:

5. Apakah jenis kelamin lawan bicara menentukan kata ganti yang anda gunakan? Tolong jelaskan:

6. Dalam situasi apa anda menggunakan kata ganti ulun dan pian saat berbicara Bahasa Banjar? Tolong jelaskan: 
7. Dalam situasi apa anda menggunakan kata ganti aku dan ikam saat berbicara Bahasa Banjar?

Tolong jelaskan:

8. Dalam situasi apa anda menggunakan kata ganti unda dan nyawa saat berbicara Bahasa Banjar? Tolong jelaskan:

9. Dalam situasi apa anda menggunakan kata ganti buhan pian/ buhan sampiyan/buhan ikam/buhan nyawa saat berbicara Bahasa Banjar? Tolong jelaskan:

10. Dalam situasi apa anda menggunakan kata ganti sidin dan inya saat berbicara Bahasa Banjar? Tolong jelaskan:

11. Dalam situasi apa anda menggunakan kata ganti nang ini dan nang itu saat berbicara Bahasa Banjar? Tolong jelaskan:

12. Pernahkah anda menyebut diri sendiri menggunakan kata saurang ini, kita ini, yayang ini dll untuk menyebut diri sendiri? Tolong jelaskan:

13. Apa saja kata ganti yang pernah anda gunakan selain yang disebutkan di atas? Dalam situasi seperti apa biasanya? Tolong jelaskan:

TERIMA KASIH

\section{APPENDIX C}

It is a questionnaire on the use of American English Personal Subject Pronoun among the English Department Students of Unlam Batch 2012 based on their knowledge and daily use of the English pronouns. 


\section{QUESTIONNAIRE C}

This research is aimed at gathering data on the use of American English Personal Subject Pronoun among the English Department Students of Unlam Batch 2012. Please answer the questions based on your knowledge and your daily use of the pronouns. Thank you.

1. What are the $1^{\text {st }}$ personal subject pronoun that you know and use when you speak English?

2. What are the $2^{\text {nd }}$ personal subject pronoun that you know and use when you speak English?

3. What are the $3^{\text {rd }}$ personal subject pronoun that you know and use when you speak English?

4. What are the singular personal subject pronoun that you know and use when you speak English?

5. What are the plural personal subject pronoun that you know and use when you speak English?

6. Do you think in using the personal subject pronoun you need to consider the situations (official/unofficial)? Why? Why not?

7. Do you think in using the personal subject pronoun you need to consider the degree of intimacy? Are they different when you speak to your boyfriend/girlfriend, close friend, parents, siblings, etc. Why? Why not?

8. Do you think in using the personal subject pronoun you need to consider the social status in terms of marriage and occupation? Are they different when you speak to someone whom you know that he/she is married or unmarried? Are they different when you speak to someone whom you know or don't know what the job is? Why? Why not?

9. Do you think in using the personal subject pronoun you need to consider the age of the person? Why? Why not?

10. Do you think in using the personal subject pronoun you need to consider the sex of the person? Why? Why not?

APPENDIX D

It is the data tabulation on the use of personal subject pronoun by native speakers of Banjarese with Banjar Kuala Dialect (BKD)

\section{APPENDIX E}

It is the data tabulation on the use of personal subject pronoun by native speakers of Banjarese with Banjar Hulu Dialect (BHD) 
It is the data tabulation on the raw qualitative data for Appendix A, B and C.

\section{REFERENCES}

[1] Deejieta. (2012). Kata Sapaan dalam Bahasa Banjar. http://dee-jieta.blogspot.com/2012/06/kata-sapaan-dalam-bahasabanjar.html (accessed 18/11/2013).

[2] Helmbrecht, J. (2014). Politeness distinctions in personal pronouns - a case study in competing motivations. In MacWhinney, B., Malchukov, A., \& Moravcsik, E. (Eds), Competing Motivations in Grammar and Usage. Online: Oxford University Press.

[3] Indradi, A. (2008). Tata Bahasa Banjar. http://tatabahasabanjar.blogspot.com/ (accessed 6/10/2011)

[4] Kartomiharjo, S. (1979). Ethnography of Communicative Codes in East Java. Unpublished Thesis: Cornell University

[5] Nguyen Ming Tranh. (2011). A Contrastive Analysis of Personal Pronouns in English and Vietnamese https://www.google.com/url?sa=t\&rct=j\&q=\&esrc=s\&source=web\&cd=1\&ved=0ahUKEwjPmr6qhd3Q AhWMK48KHVJmAncQFggeMAA\&url=http\%3A\%2F\%2Fkhoaanh.net\%2F_upload\%2FCA2011\%2F 4A08_Nguyen_Minh_Trang_A_Contrastive_Analysis_of_Personal_Pronouns_in_English_and_Vietnamese .docx\&usg=AFQj CNFaAiYggwXpj375lF8PzJJ28V1iWA\&sig2=dpc9dBni8 TZ9d7PchFPm3g\&ca d=rja (accessed 1/11/2013).

[6] Okamura, A. (2002). What do you call colleagues at work? In The Economic Journal of Takasaki City, University of Economics. 45. 1. 71-94. http://www1.tcue.ac.jp/home1/k-gakkai/ronsyuu/ronsyuukeisai/45_1/okamura.pdf (accessed 6/10/2011).

[7] Richards, J. C. \& Schmidt, R. (2002). Longman Dictionary of Language Teaching and Applied Linguistics (Third Edition). Pearson Education Limited: London

[8] Stern, H.H. (1983). Fundamental Concepts of Language Teaching. Oxford: Oxford University Press.

[9] Wales, Katie. (2004). Second Person Pronoun in Contemporary English: The end of a story or just the beginning? In FrancoBritish Studies 33: 172-185. cvc.cervantes.es/lengua/coloquio_paris/ponencias/pdf/cvc_wales.pdf (accessed 5/11/2013).

[10] Wardhaugh, R. 1998. An Introduction to Sociolinguistics (Third Edition). Oxford: Blackwell Publishing Ltd.

[11] www.urangbanua.com. (2011). Kamus Bahasa https://www.google.com/url?sa=t\&rct=j\&q=\&esrc=s\&source=web\&cd=1\&cad=rja\&uact=8\&ved=0ah UKEwiTxu uO_dzQAh WKsI8KHfwXAr0QFggZMAA\&url=http\%3A\%2F\%2Fp $\quad$ 2b.uns.ac.id\%2Fa r\%2Fuserfiles\%2Ffiles\%2FKamus\%2520Bahasa\%2520Ba njar.pdf\&usg=AFQjCN EnDFdkf3TXrmv4 UlpcanVREnNvIw\&sig2=Z3Ok-L-tk84bOAAiIxb3Hg\&bvm=bv.139782543,d.c2I (accessed 6/10/2011).

[12] Yamaji, H. (2000). Addressee-Oriented Nature of Referent Honorifics in Japanese Conversation. Texas Linguistic Forum 44(1): 190-204 Proceedings from the Eighth Annual Symposium about Language and Society-Austin April 7-9, 2000.

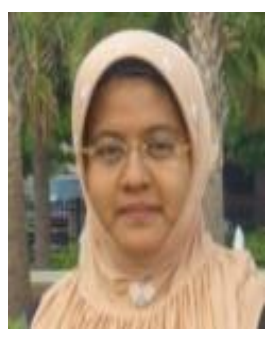

Elvina Arapah is a faculty member in the English Department of Universitas Lambung Mangkurat, Banjarmasin, South Kalimantan, Indonesia. She earned her Master of Arts in English Language Education from Universitas Negeri Malang, Malang, East Java, Indonesia.

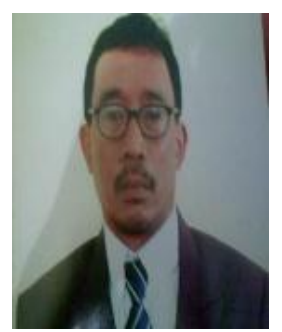

Fatchul Mu'in is a Lecturer in Literature/ Linguistics at Universitas Lambung Mangkurat, Banjarmasin, South Kalimantan, Indonesia. He earned his Master of Humanities from Universitas Gadjah Mada, Yogyakarta, Indonesia and Doctoral degree from Universitas Negeri Malang, East Java, Indonesia. 